研究

\title{
パルス通電接合面間での挿入粉末挙動
}

\author{
近藤 克哉的 1 , 油座 健二放 2 , 和田 光司的 3 , 大橋 修的 4 \\ 的1 新潟工業短期大学, $=950-2076$ 新潟市西区上新栄町 5-13-7.

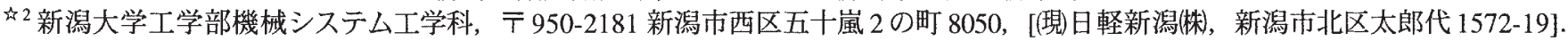 \\ 姡 $\mathrm{SMC}$ (侏)，广300-2493つくばみらい市絹の台 4-2-2。 \\ 的 4 新潟大学自然科学研究科, $\bar{\top} 950-2181$ 新潟市西区五十嵐 2 の町 8050.
}

\section{Behavior of Powder as Interlayer Materials of Joints in Pulsed Electric Current Bonding}

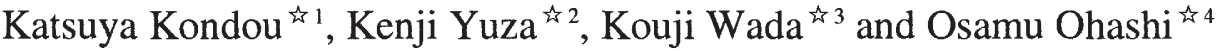 \\ ${ }^{2}$ Niigata College of Technology, 5-13-7 Kamishin'ei-cho, Nishi-ku, Niigata 950-2076, Japan. \\ ${ }_{4}^{2}$ Dept. Mech. sys., Fac. Eng., Niigata University, 8050 Ikarashi Nino-cho, Nishi-ku, Niigata 950-2181, Japan. \\ ${ }^{43}$ SMC Co.,Ltd., 4-2-2 Kinunodai, Tsukubamirai, 300-2493, Japan. \\ ${ }^{\sim^{4}}{ }^{4}$ Graduate School of Science and Technology, Niigata University, 8050 Ikarashi Nino-cho, Nishi-ku, Niigata 950-2181, Japan.
}

Received September 28, 2007

\section{SYNOPSIS}

In pulsed electric current bonding, local heating at the contact area is accelerated. As the results, it is afraid that the powder as interlayer materials of joints is dispersed during the bonding. In this study $6063 \mathrm{Al}$ joints using powder as interlayer were formed at various bonding conditions such as powder (composition, mass), bonding pressure and electric wave (frequency, duty ratio). The powder loss and melted area at bonded joints were investigated to clarify the behavior of powder.

It was found that the powder is dispersed and melted around bonded interfaces during the pulsed electric current bonding. Powder loss ratio and melted area ratio at the joints increase with the increase of powder mass, initial current, duty ratio, and the decrease of bonding pressure. Phenomena of dispersion and melting using powder as interlayer are not affected by the current frequency and powder composition. The phenomenon of powder dispersion depends on the gas emission of $\mathrm{H}_{2} \mathrm{O}$ and $\mathrm{H}_{2}$ from powder. The decrease of powder mass and the initial current, and the increase of bonding pressure are recommended in the selection of bonding conditions to decrease the gas emission.

\section{KEY WORDS}

powder, interlayer materials, bonding, pulsed electric current bonding, aluminum alloy

\section{1 緒言}

通電接合法は被接合材にパルス状の電流を通電して, 接合 部で発生するジュール熱を用いて接合する固相接合法である. 本通電接合法についての適用研究も活発で, 接合時の通電初 期の電流波形 ${ }^{1)}$ 及び通電接合条件の選定指針等 ${ }^{23)}$ についても 検討されている.

本法は, 接合部を直接加熱することができることから， ヒーターを用いて接合部を傍熱する間接加熱法と比較して, 接合部を効率的に加熱できる特徵を持っている.この観点か ら, 通電接合法は接合部の効率的な加熱接合法として注目さ れている4).

接合物を接触させて通電接合する際，接合面間での発熱量 は, 接触面間の電気抵抗と通電電流に大きく依存する.また,
電気抵抗は接合面の表面粗さと接合圧力等に依存する ${ }^{2.37}$. 接 合面間の発熱量を増加させる方法として, 接触抵抗を増加さ せる方法が考えられる。

そこで，接合面間の発熱を促進するため，接合面間の接触 抵抗を増加させることを目的として，接合面間に粉末を挿入 して接合する方法に着目した．さらに，Ti と $\mathrm{Al}-1 \mathrm{Mg}$ の二種 類の粉末の混合粉末を使用することで, 接合中に両粉末の燃 焼合成反応が発生して ${ }^{5,6)}$, さらに接合部を効率的に加熱出来 る可能性もある。このように，接合面間に粉末を挿入するこ とで, 接合部の効率的な加熱も期待できるが，接合部に㨂入 した粉末が飛散し，接合面間からの脱落も予想される.

本研究では, 接合面間に挿入した粉末の挙動 (粉末の減少 量, 溶融量) と, 通電接合条件因子 (粉末の組成, 粉末量, 圧 
力, 電流波形) との関係について検討し, 挿入粉末の飛散・脱 落を減少させ, 通電接合する際の接合条件因子の選定指針に ついて検討した.

\section{2 実験方法}

供試材は $6063 \mathrm{Al}$ 合金で，その組成は，0.44Si-0.21Fe-0.03Cu$0.01 \mathrm{Mn}-0.01 \mathrm{Cr}-0.01 \mathrm{Ti}-0.50 \mathrm{Mg}-\mathrm{Al}$ である.この供試材を直径 $30 \mathrm{~mm}$, 長さ $25 \mathrm{~mm}$ に機械加工し, 丸棒形状の接合試料を作 製した。そその端面を接合面とした。 その接合面の粗さは， Rz: $50 \mu \mathrm{m}$ である. 接合の直前に, これら接合材をアセトン中で 超音波洗浄した.

接合面間に挿入した粉末は, $\mathrm{Al}-1 \mathrm{Mg}$ 粉末 (組成: $0.22 \mathrm{Si}$ $1.1 \mathrm{Mg}-\mathrm{Al}$ ), Ti 粉末 (組成: $0.006 \mathrm{Fe}-0.001 \mathrm{Cr}-\mathrm{Ti}$ ) で, 平均粒径 はそれぞれ $130 \mu \mathrm{m}, 45 \mu \mathrm{m}$ である.

接合に際しては, 真空容器内に接合試料を突き合わせて設 置し，カーボンスペーサーで挟み，電極間に設置した。接合 圧力で加圧後, 雾囲気圧力が 6 Pa以下に真空容器内を排気後, 所定の電流を直接通電して昇温し，接合温度近傍で初期の通 電電流を低下させて接合温度を制御し，接合温度に $5 \mathrm{~min}$ 間 保持した. 接合圧力は通電接合中一定に保持した. 接合温度 は, 接合界面から $5 \mathrm{~mm}$ 離れた個所に， $\mathrm{K}$ 熱電対を固定して測定 した. 使用したパルス通電接合装置は, PLASMAN CSP-II5SS (エスエスアロイ製)である. 本実験で使用したカーボン スペーサー(東洋炭素怢製，ISO-88)の形状は直径 $60 \mathrm{~mm}$, 高 さ $20 \mathrm{~mm}$ の円盤形状である.

接合中に放出されるガスの組成と分圧測定には, ガス分析 装置を用いた。 ガス分析装置は, アネルバ侏製 M-100QA-F 四重極型質量分析計とターボ分子ポンプから構成される. 本 装置は, バリアブル・リーク・バルブを介して真空容器に接 続した. ガス分析装置内の雾囲気圧力を $1 \times 10^{-3} \mathrm{~Pa}$ 以下に排 気後, バリアブル・リーク・バルブを開き, 真空容器内のガ スを導入して, ガス分析した. 分析条件は, 質量数 $0 \sim 60$ の 範囲として,この間 $6 \mathrm{~s} て ゙$ 走査し，接合中の放出ガスを連続的
に記録した。

通電接合条件によっては, 粉末が飛散し, 接合面間の粉末 量が減少する. 接合前後の粉末の質量減少割合を粉末減少率 と定義した. また, 破面には部分的に溶融箇所が観察される. 接合面上でのその面積割合から溶融面積率と定義した.

\section{3 実験結果}

まず最初に，接合面間に粉末を挿入して，真空中，直流電 流 $2500 \mathrm{~A}$, 接合压力 $0.7 \mathrm{MPa}$, 温度 $600^{\circ} \mathrm{C}$, 時間 $5 \mathrm{~min}$ 保持し て接合した. 接合面間には, $\mathrm{Al}-1 \mathrm{Mg}$ 粉末 $(0.566 \mathrm{~g}), \mathrm{Ti}$ 粉末 $(0.988 \mathrm{~g})$ 及び両粉末を原子比で $1: 1$ に混合した粉末 $(0.950 \mathrm{~g})$ の3 種類の粉末を挿入した継手を作製し，挿入粉末の種類の 影響を検討した。粉末量は, 密度が $100 \%$ となった時, いず れの粉末挿入時でも, 厚さが $0.31 \mathrm{~mm}$ となるように選定した. 混合粉末では通電接合時, 燃焼合成で接合面がさらに加熱さ れることを期待して使用した。

Fig.1 は, 接合後, 継手を曲げ破壊して, その破面の観察例 を示す. (A) はAl-1Mg粉末, (B) はTi粉末, (C) はAl-1Mg と $\mathrm{Ti}$ の混合粉末挿入時の破面写真である.いずれの場合も, 破 壊は粉末層内で発生した. (A)の $\mathrm{Al}-1 \mathrm{Mg}$ 粉末挿入時の場合, 粉末層の他, 粉末が接合面間から脱落して Al合金地金が直接 観察される箇所と, 溶融箇所が観察される. (C)の混合粉末挿 入時も，似たような破面形態を示した。一方，(B)の Ti 粉末 使用時には, 溶融箇所が観察されなかった.

そこで, 接合面でのこの粉末の飛散・隇少と, 溶融に着目 して, 各種の継手から粉末の減少率 (接合前後の質量差を接 合前の質量で割った割合)，溶融面積率(溶融箇所の面積割合) を測定した.

Fig.2には各種の接合温度の継手の粉末減少率と接合温度と の関係, Fig.3には接合面での溶融面積率と接合温度との関係を 示す.いずれも，接合面間には $\mathrm{Al}-1 \mathrm{Mg}$ 粉末 $(0.566 \mathrm{~g})$, Ti粉末 $(0.988 \mathrm{~g})$ 及び両粉末を原子比で $1: 1$ に混合した粉末 $(0.950 \mathrm{~g})$ の3 種類の粉末を挿入した継手を作製し，挿入粉末の種類の

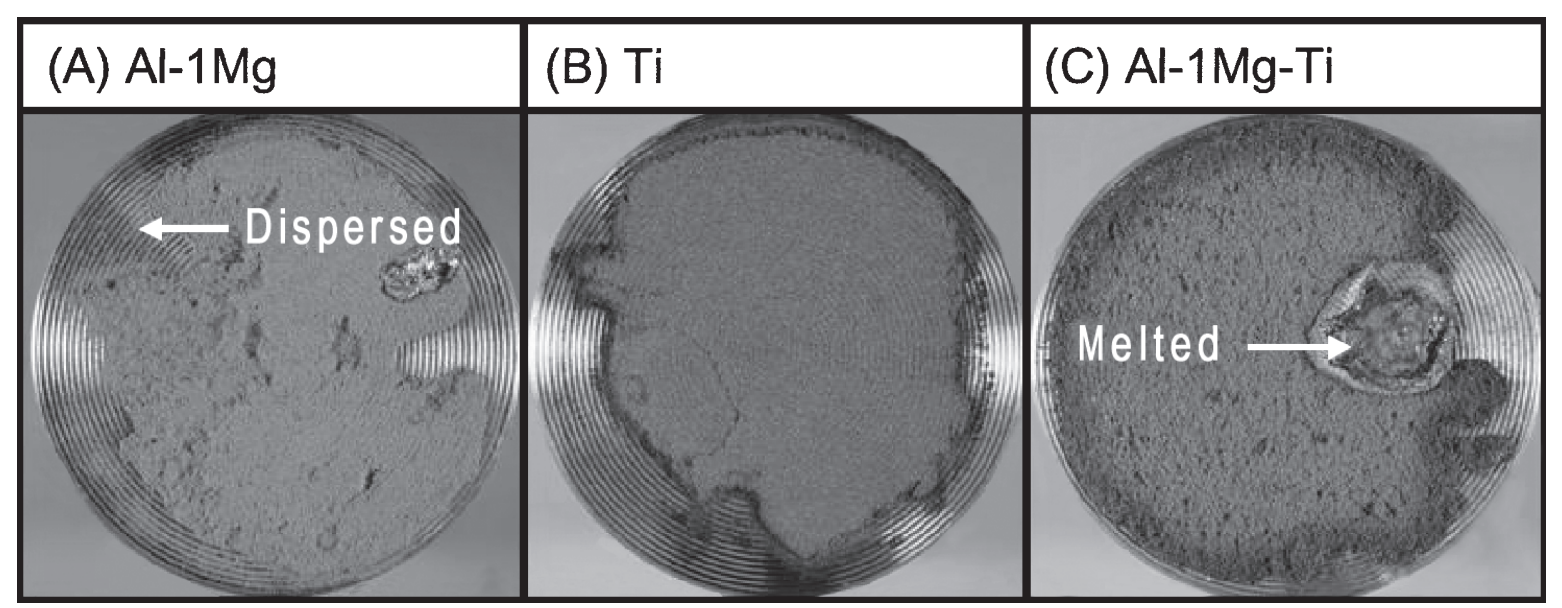

D.C2500A, $600^{\circ} \mathrm{C}, 0.31 \mathrm{~mm}$, in vacuum

Fig.1 Fracture of joints with (A) Al-1Mg powder, (B) Ti powder and (C) Al-1Mg-Ti powder. 


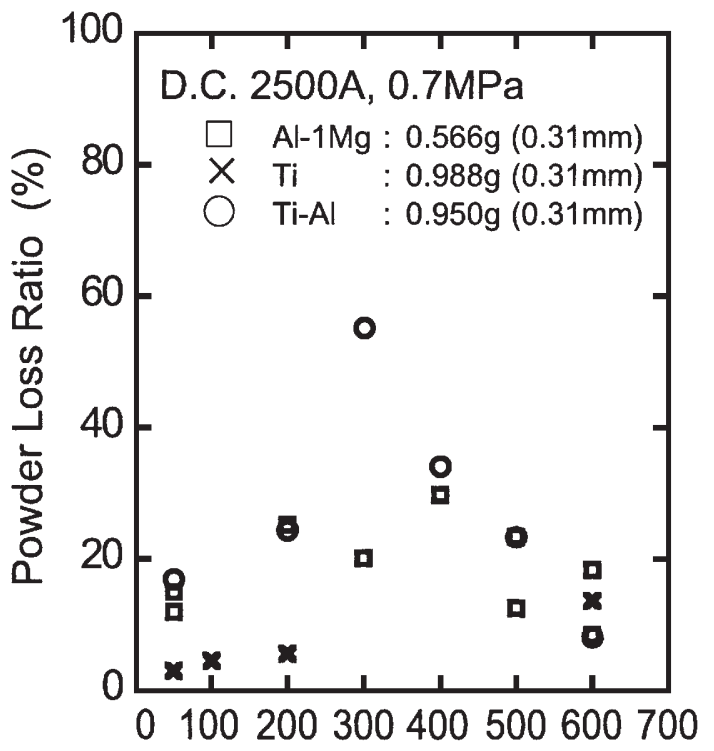

Bonding Temperature, $T_{B} /{ }^{\circ} \mathrm{C}$

Fig.2 Effect of bonding temperature on powder loss ratio of joints with $\mathrm{Al}-1 \mathrm{Mg}$ powder, Ti powder and $\mathrm{Al}-1 \mathrm{Mg}-\mathrm{Ti}$ powder.

影響を検討した. Fig.2の粉末減少率の結果から, $\mathrm{Al}-1 \mathrm{Mg}$ 粉 末, $\mathrm{Ti}$ と $\mathrm{Al}-1 \mathrm{Mg}$ 混合粉末の減少率は, Ti粉末よりも大きい. そして, 接合温度が $100^{\circ} \mathrm{C}$ の継手においても, 粉末の減少が 見られる. Fig.3は溶融部の面積測定から算出した溶融面積率 の結果であるが, Al-1Mg粉末, $\mathrm{Ti}$ と Al-1Mg混合粉末の継手 では, 溶融量はTi粉末よりも大きい。 また, 通電直後で接合 温度が $100^{\circ} \mathrm{C}$ の継手においても, 粉末が飛散し, 接合面間の 粉末の溶融した継手がある.

通電接合による粉末の飛散時期を観察するため, 通電前後 の接合試料の外観を観察した. その結果を Fig.4に示す. (A) は試料を装置に取り付けた際の写真であるが, 接合試料取り 付け時に, 粉末が接合面から少し脱落する事が多い. (B) は, 真空に排気後の外観写真である. 排気により粉末間の大気も

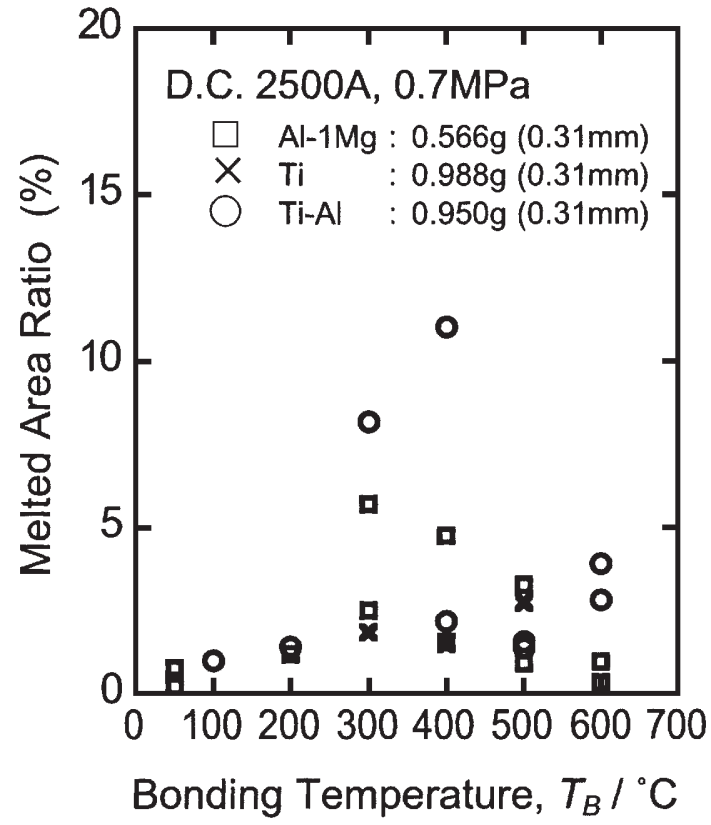

Fig.3 Effect of bonding temperature on melted area ratio of joints with $\mathrm{Al}-1 \mathrm{Mg}$ powder, Ti powder and $\mathrm{Al}-1 \mathrm{Mg}-\mathrm{Ti}$ powder.

排気されるが,この排気による粉末の飛散はない. (C)は接合 部に約 $1 \mathrm{~s}$ 通電後の外観写真で, 試料温度は約 $50^{\circ} \mathrm{C}$ となった. 接合試料の温度は低いが，接合面間の粉末が脱落して，ス ペーサー上に飛散しているのが分かる. 粉末の飛散量は, 試 料取り付け時よりも, 通電による粉末の飛散量が圧倒的に多 $<$, 粉末の飛散率は通電に依存する.

次に, 混合粉末で大きな溶融促進効果が観察されなかった ことから, $\mathrm{Al}-1 \mathrm{Mg}$ 粉末を用いて, 接合圧力, 粉末量, 電流値 と波形等の粉末減少率, 溶融面積率への影響について検討し た.

Fig.5に, 挿入粉末 $\mathrm{Al}-1 \mathrm{Mg}$ の減少率, 溶融面積率に及ぼす 接合圧力の影響を示す. 粉末の減少率, 溶融率とも, 接合圧 力の増加とともに, 減少した.

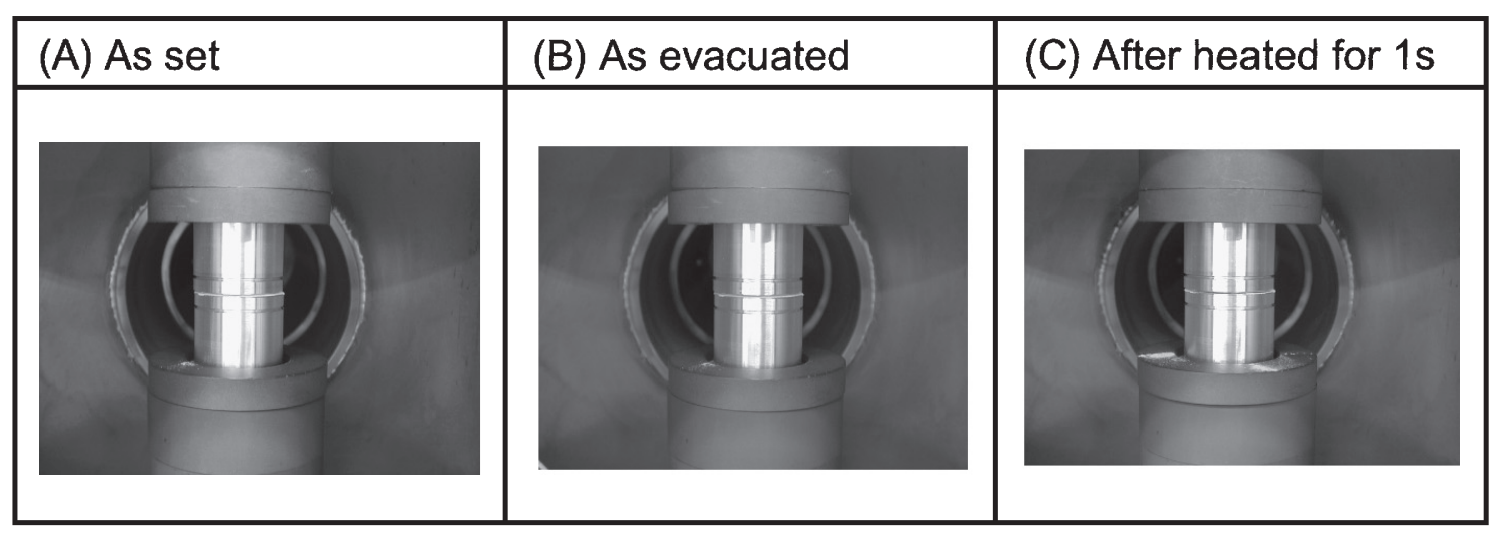

D.C2500A, 0.5MPa, $0.31 \mathrm{~mm}$, in vacuum

Fig.4 Dispersed powder appearance at joints (A) as set in chamber, (B) as evacuated and (C) after heated for $1 \mathrm{~s}$. 


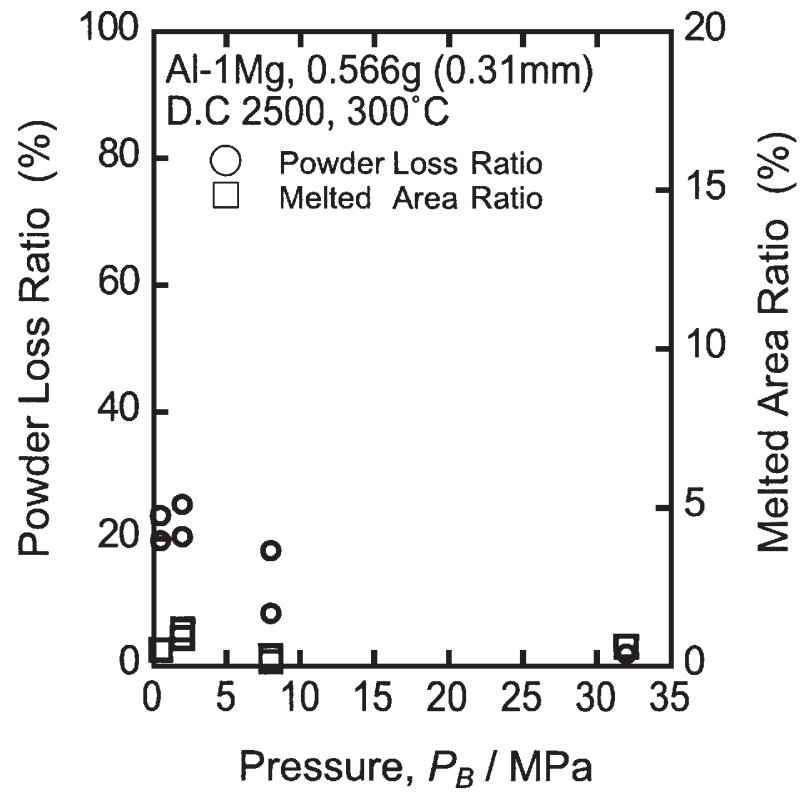

Fig.5 Effect of bonding pressure on powder loss ratio and melted area ratio at joints.

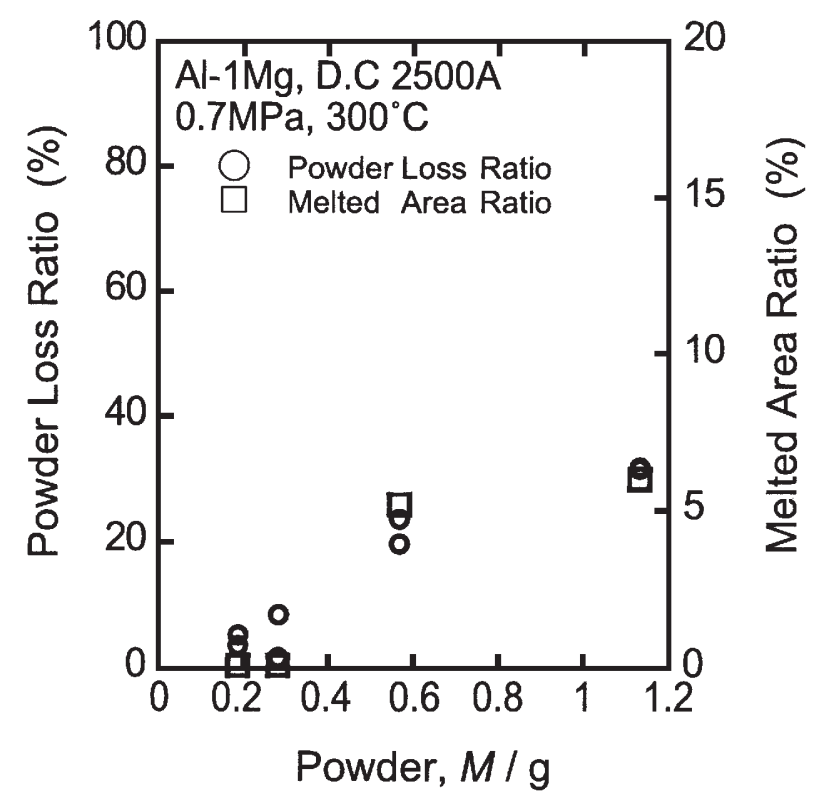

Fig.6 Effect of powder mass on powder loss ratio and melted area ratio at joints.

Fig.6は粉末量の減少率, 溶融面積率に及ぼす挿入粉末の影 響を示す。粉末量が減少すると, 粉末の減少率, 溶融面積率 が減少した。

次に電流值, パルス波形 (デューティー比, 周波数)の影響 について検討した. 本実験では通電開始直後から通電電流を 一定に保持し, 接合温度近傍で, 電流を減少させ, 接合温度 に保持している.

Fig.7は, この通電初期の電流值を変化させて, 接合圧力 0.7 $\mathrm{MPa}$ ，接合温度 $300^{\circ} \mathrm{C}$, 粉末量: $0.566 \mathrm{~g}$ での接合結果である.

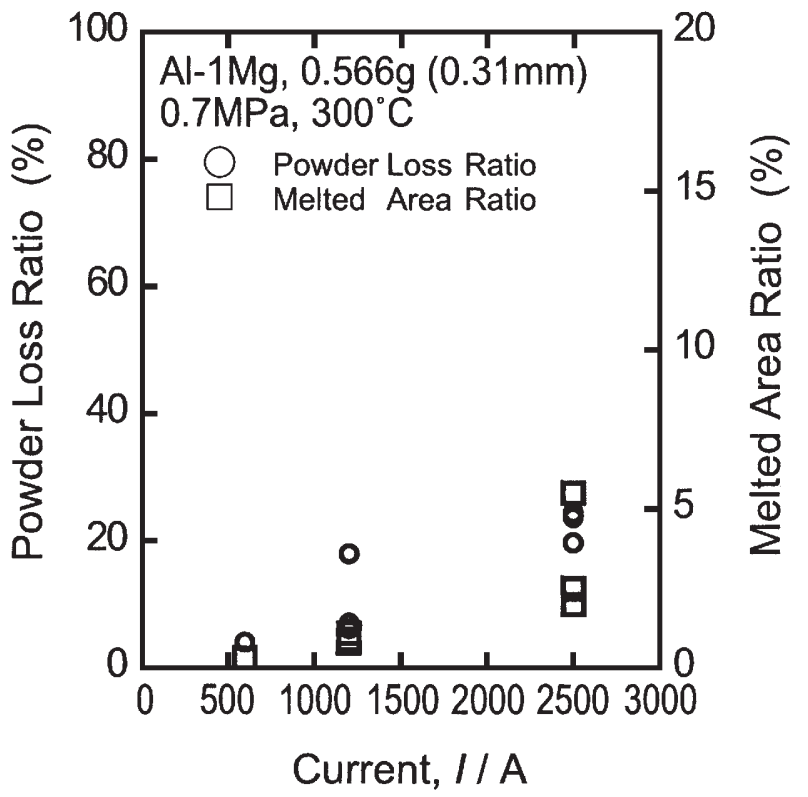

Fig.7 Effect of electric current at bonding on powder loss ratio and melted area ratio at joints.

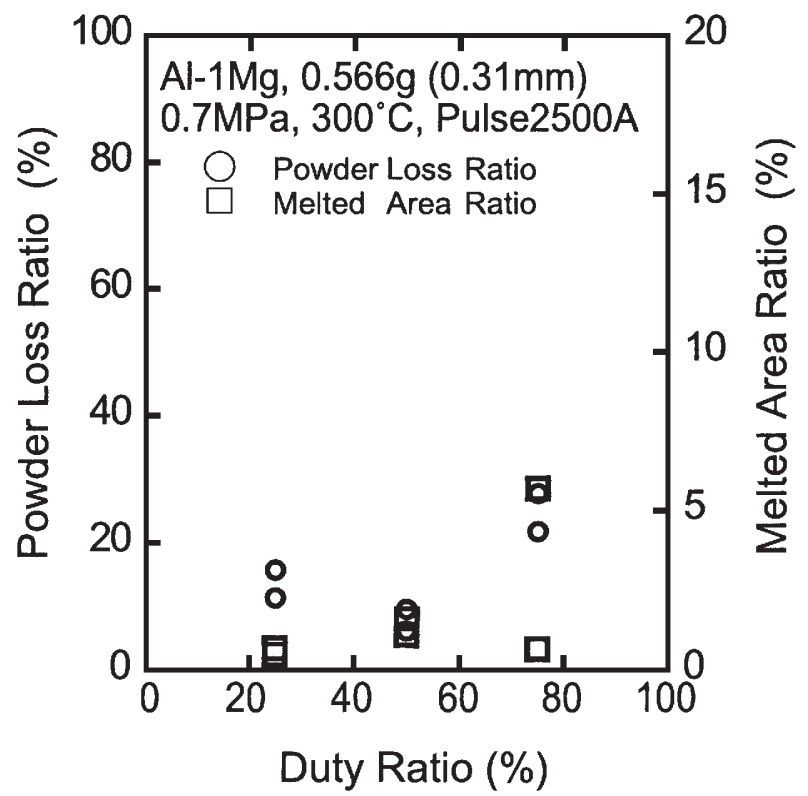

Fig.8 Effect of duty ratio of electric current on powder loss ratio and melted area ratio at joints.

通電初期の電流値が増加すると, 接合部の加熱速度も増加す る. 図に見られるように, 通電初期の電流値の増加とともに, 粉末の減少率, 溶融率ともに増加した.

次に, パルス波形の影響について検討した. 本装置は, 接 合部に矩形波の電流を流すことができる，そこで，矩形波形 の周波数を $1 \mathrm{~Hz}$ として, デューティ一比を変化させた. デューティー比とは, 1 周期での矩形波形の通電時間割合で, $25,50,75 \%$ と変化させた.

Fig.8はデューティー比の接合部の粉末減少率と溶融面積率 
への影響を示す. デューティー比の増加とともに, 粉末の減 少率, 溶融面積率とも増加した.

Fig.9は, 周波数の接合面間の粉末減少率, 溶融率への影響 を示す. パルスの周波数は, 接合部の粉末の飛散, 溶融状況 にほとんど影響しない。

以上の結果, 接合面に粉末を挿入して通電接合すると, 接 合面間の粉末が飛散する. 接合部の粉末が飛散して減少する 割合は, 接合圧力の低下, 挿入粉末量の増加, 初期通電電流 の増加とともに，大きくなった．また，電流の波形の観点か らは，周波数には関係なく, デューティー比の増加とともに 接合部の粉末が飛散し，減少しやすい．また，粉末の減少量 の大きい継手には, 接合部での溶融量も大きくなる傾向にあ る事が明らかとなった.

\section{4 考察}

粉末を接合面間に挿入して通電接合した際，粉末が溶融， 飛散等の現象が見られ,これらの現象は接合条件因子に依存 することが明らかとなった. 粉末が飛散して, 接合面間の粉 末が減少する原因について考察する.

測定した粉末の滅少率, 溶融面積率に測定結果のばらつき が大きいが,これは接合面間に均一に粉末を挿入することは 困難であることから, 測定結果のばらつきは粉末の挿入状態 のばらつきに依存すると考える.

まず, $\mathrm{Al}-1 \mathrm{Mg}$ 之Tiの混合粉末で燃焼合成は期待できるが5,6), 実際の接合部には, 局所的な溶融が確認できるのみであった. しかし, $\mathrm{Al}-1 \mathrm{Mg}$ 粉末と $\mathrm{Ti}$ 粉末の単独粉末を挿入した場合と 比較して, 溶融領域に大きな差異は認められず, 混合粉末使 用時の優位性は特に観察されなかった。

本実験での挿入粉末部の形状は円盤状である，最大厚さ 0.6

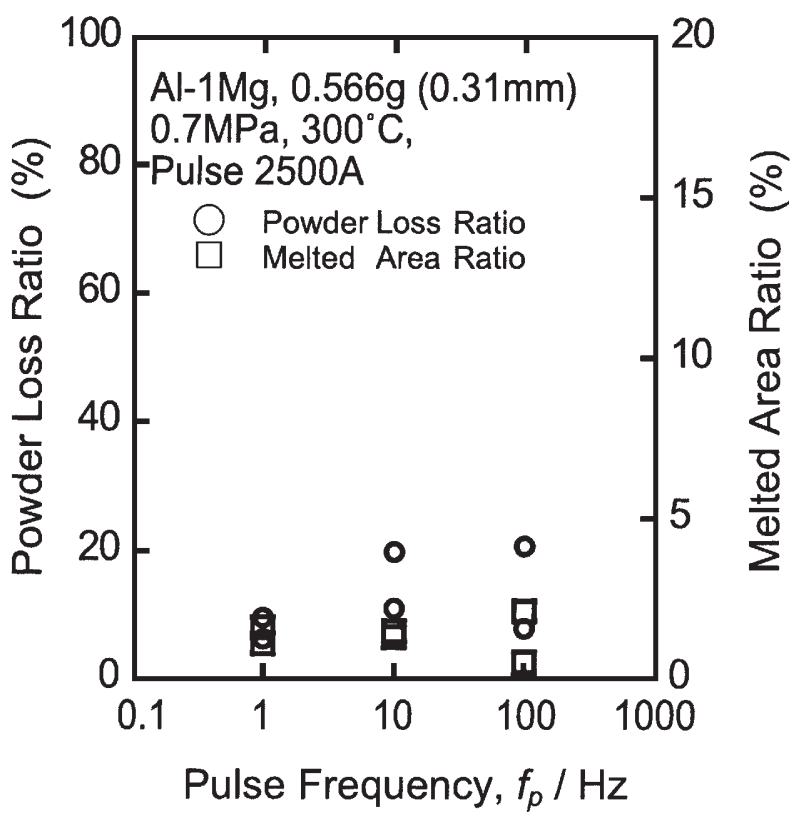

Fig.9 Effect of pulse frequency of electric current on powder loss ratio and melted area ratio at joints. $\mathrm{mm}$ であり, 粉末の平均粒径は, $\mathrm{Al}-1 \mathrm{Mg}$ 粉末で $130 \mu \mathrm{m}, \mathrm{Ti}$ 粉 末で $45 \mu \mathrm{m}$ である. 接合粉末の断面部で, 数個の $\mathrm{Al}-1 \mathrm{Mg}$ 粉 末と数個のTi粉末の混合層と考えられる.ナノレベルでAlと $\mathrm{Ni}$ を 1000 層程度積層した䇴を使用することで，接合部のみ を加熱して接合する技術が報告されている》ことから，粉末 粒子径をさらに小さくする事で, 燃焼合成が期待できる.

接合面に粉末を挿入して通電接合すると, Fig.2, Fig.3に示 すように, 接合面間の粉末が飛散, 溶融する. Al-1Mg粉末と 比較し, Ti 粉末の溶融面積率が低いのは, Ti粉末の溶融点が 高いことが考えられる.この接合面間の粉末の減少量は, 接 合圧力の低下, 挿入粉末量の増加, 初期通電電流の増加とと もに, 大きくなった. また, 電流の波形の観点からは, 周波 数には影響されない.これは, 通電パルス周波数が変化して も, デューティー比が一定なことから, 通電電力は一定で, 周 波数は接合面間の発熱量に影響しない. その結果, 粉末の減 少率と溶融率が変化しないと考えられる. デューティー比を 変化させた場合, ピーク電流値は変わらない. 投入電力に変 化を及ぼすのは電流がONになっている時間である. ON時間 が長くなると投入電力が大きくなり, 発熱が大きくなる.し たがって, デューティー比が増加すると, 通電時間割合が増 加することから, 電力が増加して接合面間での発熱量が増加 する. この結果, 接合面間の発熱量が増加し, 粉末の減少率 と溶融率が増加すると考えられる.

次に, この粉末の飛散が発生する理由について検討する. 接合時の接合容器内の雾囲気圧力の変化から検討する. 通電 開始とともに接合雾囲気圧力が上昇し, 最大值到達後減少す る. 通電による圧力変化を測定した.

Fig.10には，接合面間に $\mathrm{Al}-1 \mathrm{Mg}$ 粉末及び $\mathrm{Ti}$ 粉末を挿入し て通電接合した時と, 粉末を使用しない時の接合雾囲気圧力 変化の測定結果を示す. 接合雾囲気圧力の変化は, 通電直後 にガスが放出され，接合雾囲気圧力が大きく上昇している. $\mathrm{Al}-1 \mathrm{Mg}$ 粉末を挿入した時の圧力変化が大きい. $\mathrm{Ti}$ 粉末挿入 時の圧力変化が粉末を使用していない時より少ない原因は,

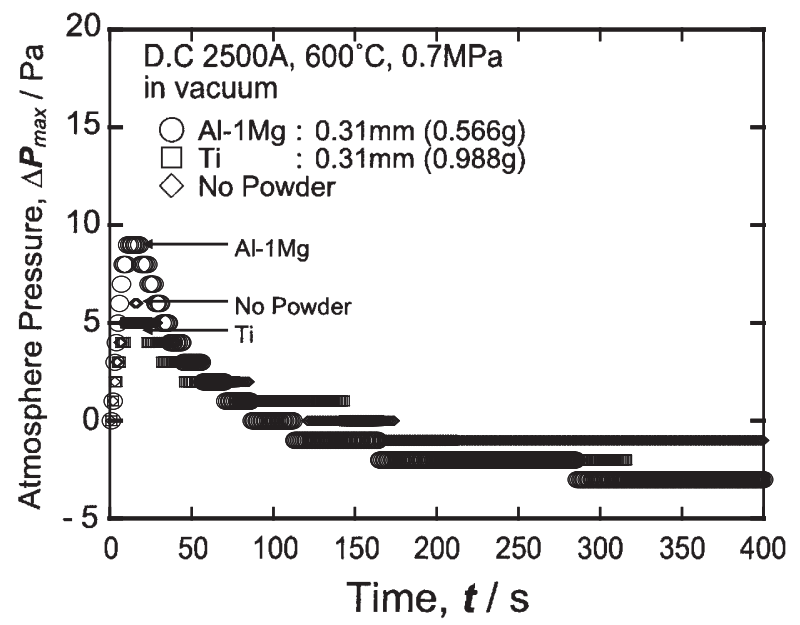

Fig.10 Change of atmosphere pressure at joints with $\mathrm{Al}-1 \mathrm{Mg}$ powder, Ti powder and no powder during bonding. 


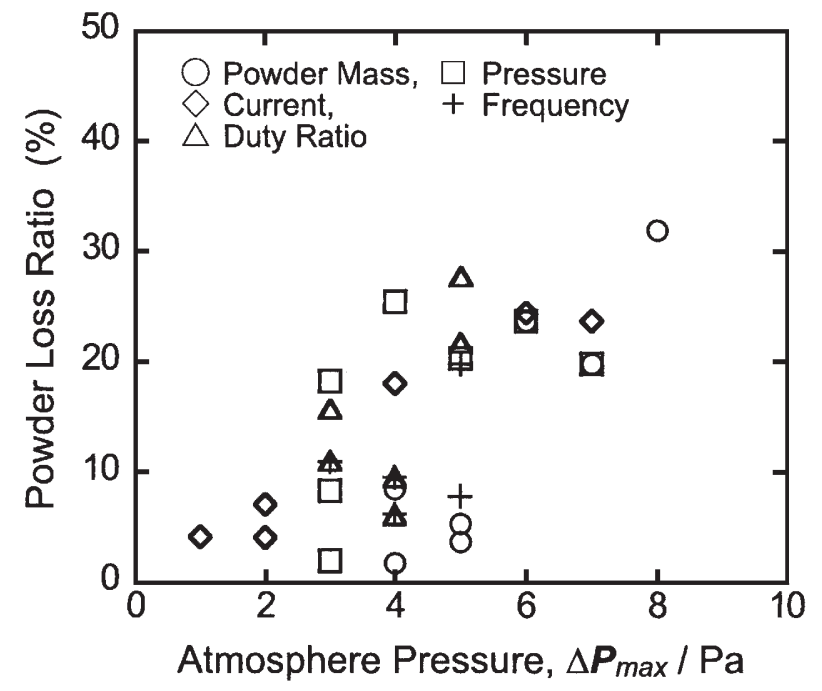

Fig.11 Relationship between powder loss ratio and change of atmosphere pressure at various bonding conditions.

Tiが加熱下でのガス吸収性が優れ，ガス吸収したためと考え られる。

次に, 各種条件で接合した際の, この雾囲気圧力の変化之 粉末減少率との関係を整理した結果をFig.11に示す. 図は, 粉 末量, 接合圧力, 電流, 周波数, デューティ一比を変化させ た時の結果である. ばらつきが大きいが, 接合雾囲気圧力の 変化が大きくなると, 粉末減少率が増加する傾向にあること が分かる.

次に, 接合䨌囲気の変化の原因を検討するため, 粉末から ガスが放出されていることが予想されることから, 接合装置 に超高真空に排気した質量分析装置を接続して, 接合中に放 出されるガス分析を行った. その結果をFig.12に示す. 図は, $\mathrm{Al}-1 \mathrm{Mg}$ 粉末を接合面間に挿入した時の結果で, 接合温度, 䨌 囲気圧力 $\{$ 全圧, 水素 (質量数: 2) 分圧, 水蒸気 (質量数: 18) 分圧\}の時間的変化を示している. 質量分析装置においても 同じように接合中の接合䨌囲気圧力の変化が観察される. 接 合初期の圧力変化は, 水蒸気がほとんどである. しかし, 粉 末の温度の上昇とともに，突発的に水素の放出が見られる. 接合の初期の接合部の温度が低い時には水蒸気の放出, 高温 では, 水素の放出が支配的となる.

この水素放出について検討するため, 先の接合と同じよう な昇温速度で, 純 $\mathrm{Al}, \mathrm{Al}-2.5 \mathrm{Mg}, \mathrm{Al}-10 \mathrm{Mg}$ 粉末をカーボン型 に挿入して焼結した時のガス分析と, 各種A 1 粉末を熱分析し た時のガス分析とを比較した. その結果, 粉末の焼結時のガ スの発生は, 水蒸気の発生に引き続き, 水素の発生が見られ た. $\mathrm{Mg}$ の添加量の影響はなく，使用粉末の組成の影響はな かった。しかし, 熱分析時では, 純 $\mathrm{Al}$ では焼結時と発生挙動 は同傾向で, 水蒸気の発生に引き続き, 水素の発生が見られ た. $\mathrm{Mg}$ 含有合金では，水素の放出は減少した，水素の放出 は, $\mathrm{Al}$ 粉末を接合面間に挿入した接合時, $\mathrm{Al}$ 粉末の焼結時に

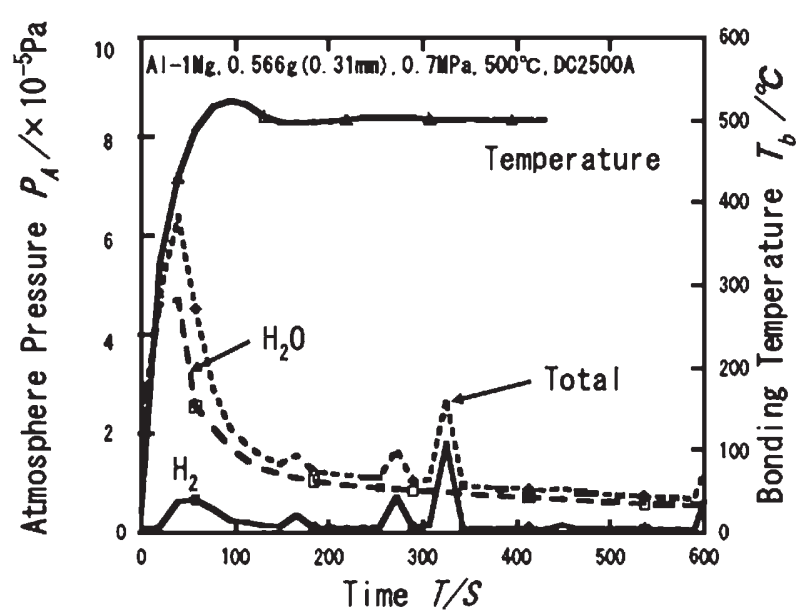

Fig.12 Compositions of emitted gas at joints with $\mathrm{Al}-1 \mathrm{Mg}$ powder during bonding.

見られる.この水素の放出はA 1 粉末の加圧下での挙動と考え られる. Alの塑性変形中に水素の放出が観察されるとの報告 がある ${ }^{8)}$. 本実験での水素放出挙動は $\mathrm{Al}$ 粉末の変形に一因あ ると考えられる。

以上の結果, 接合面間に粉末を挿入して通電接合すると, 接合圧力の低下, 粉末量の増加, 初期の通電電流を増加させ ると, 接合面間の電気抵抗で接合面間が局部的に加熱される. その結果, 局部的な溶融を発生する. 同時に粉末が急速に加 熱されることから, 粉末表面から水蒸気の放出と, さらに Al$1 \mathrm{Mg}$ 粉末の塑性変形による水素の放出がある. このガス放出 で接合面間の粉末が飛散する。

接合面間に粉末の挿入は, 接合部を効率的に加熱する事と なるが, 粉末の飛散で, 接合面間に粉末が均一に分布しない 継手となる。

従って, 粉末を接合面間に挿入して接合する場合は, 粉末 量, 初期の電流を低下させ, 接合圧力を大きくして, 接合面 間でのガス発生を少なくする接合条件を選定する必要がある.

\section{5 結言}

接合面間に挿入した粉末の挙動と, 通電接合条件因子との 関係について検討し, 挿入粉末の飛散・脱落を減少させ, 通 電接合する際の接合条件因子の選定指針について検討した.

(1) 接合面に粉末を挿入して通電接合すると, 接合面間の粉 末が飛散する.この接合面間の粉末の減少量は, 接合圧力 の低下, 挿入粉末量の増加, 初期通電電流の増加ととも に, 大きくなる. また, 電流の波形の観点からは, 周波数 には関係なく, デューティー比の増加とともに接合部の 粉末が飛散しすい。

(2) 粉末の飛散は, 接合面間からの発生する水蒸気と水素に よる。

(3) 粉末の飛散と同時に, 粉末の溶融が観察される. Al-1Mg 粉末と Ti 粉末の単独粉末を挿入した場合と比較して, 溶 
融領域に大きな差異は認められず，混合粉末使用時の優 位性は特に観察されなかった.

(4) 粉末を接合面間に挿入して接合する場合は, 粉末量, 初期 の電流を低下させ, 接合圧力を大きくして, 接合面間での ガス発生を少なくする接合条件を選定する必要がある.

\section{文献}

1) H.Furuhata, N.Chikui and O.Ohashi: "Effect of Initial Electric Current on Joints of Bonded SUS304 Stainless Steel Using a Pulse Electric Current Bonding Process", J. Japan Inst. Metals, 68(2004)511-514.

2) N.Chikui, H.Furuhata, N.Yamaguchi and O.Ohashi: "Guidelines for Using Pulsed Electric Current Bonding on Stainless Steel", J. Japan Inst. Metals, 69(2005)715-718.

3) N.Chikui, H.Furuhata, K.Wada and O.Ohashi: "Effect of Electric Current Wave on Joints in Pulsed Electric Current
Bonding", J. Japan Inst. Metals, 70(2006)146-149.

4) N.Chikui, H.Furuhata, N.Yamaguchi and O.Ohashi: "Comparison of Joints by Pulse Electric Current Bonding and Diffusion Bonding", J. Japan Inst. Metals, 68(2004)515-518.

5) A.Hibino: "Numerical Analysis of Phase Control Coditopns in TiAl Combution Synthesis", J. Jpn Soc. Powder Powder Metallurgy, 44(1997)1107-1114.

6) Y.Kaieda and N.Oguro: "Oxidation Characteristics of TiAl-Mn Material Produced by Combution Synthesis Process and Sintered by Plasma Activated Sintering", J. Jpn Soc. Powder Powder Metallurgy, 49(2002)969-973.

7) http://www.rntfoil.com/technology/tech.html

8) K.Koyama, G.Itoh and M.Kanno: "Observation of Impurity Hydrogen Evolved from Aluminum and Titanium Alloys during Deformation by means of Hydrogen Microprint Technique", J. Japan Inst. Metals, 62(1998)790-795 